\title{
Transformations Great and Small: A Review Essay
}

\section{SUSAN SESSIONS RUGH}

Transforming Rural Life: Dairying Families and Agricultural Change, 18201885, by Sally McMurry. Revisiting Rural America Series. Baltimore: Johns Hopkins University Press, 1995. xii, 291 pp. Illustrations, notes, essay on sources, index. $\$ 39.95$ cloth.

Preserving the Family Farm: Women, Community, and the Foundations of Agribusiness in the Midwest, 1900-1940, by Mary Neth. Revisiting Rural America Series. Baltimore: Johns Hopkins University Press, 1995. xiii, 347 pp. Illustrations, notes, bibliographical note, index. $\$ 39.95$ cloth.

The Transformation of Rural Life: Southern Illinois, 1890-1990, by Jane Adams. Studies in Rural Culture. Chapel Hill: University of North Carolina Press, 1994. xxx, 321 pp. Illustrations, notes, sources, index. $\$ 19.95$ paper.

THESE THREE BOOKS announce the coming of age of the new rural history. In the last decade, this field of social history has turned the historical gaze to America's countryside. An earlier agricultural history of the Midwest told a triumphant story of technological change that enabled farmers to participate fully in national and global commodity markets. In that narrative, farmers were eager capitalists, propelled into market agriculture by the spread of transportation, the invention of mechanized farm machinery, and improvements in seeds and stock. At the story's center stood the male farmer; his wife and children hovered in the shadows, mere laborers. The twentieth-century Midwest received the same treatment: farmers as central figures in

THE ANNALS OF IOWA 55 (Winter 1996). CThe State Historical Society of Iowa, 1996. 
the rise of agribusiness that made the nation a leader in world agricultural markets.

The new rural history challenged agricultural history by considering the social history of agrarian capitalism. Rural historians first inquired about the nature and timing of commercial capitalism in colonial America. The agrarian capitalism debate split into two camps: market historians who saw farmers as entrepreneurial capitalists who embraced the market, and social historians who saw farmers as traditional yeomen who resisted market agriculture. Social historians argued that farmers were more interested in leaving a legacy of family land for their children than in making money in the market. They challenged the view of farmers as profit-seeking capitalists, citing webs of reciprocal exchange of work and goods that operated outside the market. Market historians countered with proof of market exchange, but failed to explain the causes of the capitalist transition. The new rural history thus directed our attention to social relations within farm households, between farm households, and between households and markets. The transition debate, one that has since moderated, caught the attention of American historians and proved that the countryside was far more important to the rise of industrial capitalism than historians had previously thought. ${ }^{1}$

Following the lead of historians of the rural Northeast, the new rural historians of the Midwest are challenging the view of the farmer as entrepreneurial capitalist. Furthermore, they have begun to extend the boundaries of the field to include the ironic transformations of twentieth-century agrarian America. If historians of early America have been perplexed by the timing of what they called the capitalist transition, two problems bedevil historians of the Midwest: the amazing persistence of

1. For the categorizing of historians as "market" or "social," see Allan Kulikoff, The Agrarian Origins of American Capitalism (Charlottesville, VA, 1992). For arguments that capitalism was launched from the countryside, see Steven Hahn and Jonathan Prude, The Countryside in the Age of Capitalist Transformation: Essays in the Social History of Rural America (Chapel Hill, NC, 1985). The most definitive statement of the "market" position can be found in Winifred Barr Rothenberg, From Market-Places to a Market Economy: The Transformation of Rural Massachusetts, 1750-1850 (Chicago, 1992). 
family farming in an industrial age of mass production, and the sober social consequences of industrialized agriculture for rural areas in the late twentieth century. Thus, at the core of the new rural history are implacable contradictions that pit structural change against human agency. How did family farms survive in an industrialized economy? Were rural people merely victims of larger structural forces or did they willingly choose paths that would threaten the independence of the small producer?

THESE THREE VOLUMES ARE VALUABLE for the ways in which they connect the structural overhaul of rural capitalism to the subtle adjustments in farm households. Transforming Rural Life argues that farm families in nineteenth-century Oneida County, New York, willingly relinquished household cheese production to resolve tensions within the household. Preserving the Family Farm explains how the twentieth-century industrialization of agriculture in Iowa, Wisconsin, and North Dakota threatened the habits of reciprocal exchange on which farm families and communities depended. The Transformation of Rural Life analyzes how farm work and rural communities changed as farming became industrialized and dependent upon government programs. Obviously, the books by Neth and Adams are vital to understanding the history of lowa and the Midwest. Although McMurry's volume is set in New York, its analysis of dairying also can be instructive to students of the Midwest, where dairying continues to be a major part of the agricultural economy. Taken together, these books provide a sweeping view of two centuries of rural transformation.

The books are important not only for what they say, but for how they know what they say. All rely on voices from the past to paint a portrait of change at the local level. McMurry tells her story "from the bottom up" by analyzing debates in the pages of the dairy zone's agricultural press. Her expert analysis of material culture, from the tools of cheesemaking to the design of barns and cheese factories, allows her access to the most subtle changes in the ordinary life of farm families. Neth captures the voices of rural midwesterners through the use of diaries, oral histories, and reminiscences created through state and federal oral history initiatives. Women's voices allow her 
to explore the relationship between capitalist agriculture, patriarchal family relations, and the progressive pressures to redefine gender roles in farm families. As an anthropologist studying the recent past, Adams has the luxury of creating bodies of evidence through field schools, interviews, and the mapping of farmsteads. Because Adams grew up in Union County, her book is a combination of biography, autobiography, and historical ethnography.

SALLY MCMURRY'S Transforming Rural Life shifts the discussion of the capitalist transition from the eighteenth century to the industrializing, urbanizing, nineteenth-century nation. Contrary to the arguments of those who see the market as an unwanted intrusion in rural life, McMurry argues that farm family members actively participated in the shift of dairying from home to factory. To show how the farm household was key to the larger transformation, McMurry examines the social relations of cheesemaking households, the relations of households to other households and to the market, and the shift from family to wage labor. The book opens with an explanation of how cheese dairying was a specialized production scheme within a diversified agricultural system. The dairying production scheme allowed families flexibility in the marketplace while meeting most household subsistence needs. Families aimed to preserve a "competency" through pursuit of profit in the global market, sustained by webs of local exchange. By mid-century, connections to the market had intensified, but not until the Civil War was the market "ascendant."

While wartime demand for cheese was among the external forces that led to the transition to factory cheesemaking in the region, McMurry argues that household members sustained that transition. Two forces were behind the shift: class and gender. Enabled by the prosperity of cheese sales, farm families sent their children to school where they adopted new middle-class ideals that devalued farming. Conflicts over gender roles further nudged farm families out of the process of cheesemaking. Farm women sought an escape from the onerous work of cheesemaking to gain more control over their life choices. Once cheesemaking moved to the factory, however, women became 
marginalized as wage laborers in cheese factories managed by men. Freed from cheese production, farm women emerged from the household to build community ties through social and cultural activities that promoted middle-class notions of the national culture. Men's work load increased to boost production of milk through year-round dairying. McMurry argues that the transformation of rural life "should be cast as much in terms of a reallocation of labor between the sexes as of a realignment of social classes" (171).

In this remarkably well-argued monograph, McMurry counters the historical arguments that have seen farmers as either yeomen or entrepreneurs, traditionalists or progressives, in favor of seeing them as applying "traditional means to unconventional ends" (23). In the tradition of Christopher Clark's The Roots of Rural Capitalism, she synthesizes opposing sides in the rural debate to argue that the transition to capitalism was smooth and gradual, not "wrenching" and disruptive of rural life. ${ }^{2}$ This ameliorative stance is made possible partly by a highly elastic definition of the term competency. First applied to mean household production of a surplus for market, its meaning shifts over time. By the end of the nineteenth century, in McMurry's treatment, the word is redefined to accommodate an emphasis on rural consumerism. The malleability of this definition threatens to erase the distinctive rural character of a term that might also describe the aims of an urban shop owner. Some readers may wish for more human faces and fewer descriptions of cheese factory floor plans; however, the material culture analysis provides a secure footing for her claims of causality. Like Neth and Adams, McMurry would have historians look beyond accommodation and resistance, market penetration and class conflict, to see changing gender relations as a central part of the transformation of the countryside.

BECAUSE IT CONNECTS changes in the farm household to the development of modern agriculture in the Midwest, Mary Neth's Preserving the Family Farm is an authoritative addition

2. Christopher Clark, The Roots of Rural Capitalism: Western Massachusetts, 1780-1860 (Ithaca, NY, 1990). 
to the new rural history. Neth argues that early twentiethcentury family farming rested on a system of family labor, kinship ties, and neighborliness to survive an uncertain marketplace. By attending to women's habits of "making do," visiting, and domestic production, Neth discovered that small family farms increased income by cutting expenditures.

The system of reciprocal exchange was threatened by government policymakers and rural reformers who in the 1920 s and 1930 s proposed solutions to the "backwardness" of rural life. The new ideology promoted agricultural efficiency through investment of capital in new technology, but it weakened patterns of mutual assistance in farm neighborhoods. Not passive players, farm people selectively adopted modern technology to traditional means. (For example, they acquired telephones to maintain social networks.) The discontented joined grass-roots political organizations like the Non-Partisan League to speak out against government farm policy. Nevertheless, as progressive farmers adopted capital-intensive agriculture to become independent, smaller farms could not produce the cash to sustain a family on the land. The result was depopulation, a process that stifled local economic development and pushed farm children out of the countryside. Modern agriculture, Neth argues, ultimately dissolved the interdependence of rural society.

Gender is at the heart of Neth's argument about the transformation of rural society. She argues that modern agricultural policies installed a patriarchal structure that devalued women's economic contribution to the farm even as home production disappeared. This policy transformed women from domestic producers to consumers responsible for raising rural standards of living to urban levels. Thus, agricultural policy restructured rural society into two gendered spheres: men undertook the business of farming, while women tended to family and community needs. Neth gives equal coverage to changes in men's and women's roles to show how an analysis of gender can uncover the nuances of historical change at the local level.

Neth admits the limits of this model of a golden age of agriculture based on shared resources. Marginal farmers were often excluded from work exchange due to their transiency, and neighborliness seldom reached across lines of ethnicity and race. 
Neth thus may be describing not rural society as a whole, but only a stable core of farm families in a community, tied to other households through extended family relationships. Neth clearly argues that because policymakers and reformers did not appreciate the links of rural community, they put forward policies that had dire consequences for rural society despite rural people's attempts to adapt and resist. In the end, we are still not sure why rural people made choices that proved so destructive to rural community. Can we chalk it up to American individualism? Was it a class struggle between wealthy progressive farmers and marginal traditionalists? Perhaps they were simply blind to the longterm consequences of their decisions.

JANE ADAMS'S The Transformation of Rural Life projects Neth's story forward in time as she explains how agriculture in Union County, Illinois, was transformed. Adams argues that agriculture moved from a system of production dependent on neighbors and kin to an industrialized production scheme dependent on government support. The organizing concept of Adams's book is work and how it differed according to gender and class over time. The book opens with thick descriptions of seven farms that serve as the evidentiary base for the study.

Adams's analysis is divided into prewar, wartime, and postwar periods. The first six chapters (1890-1930) describe what she calls a self-provisioning family farm economy-families produced for the commercial market but made few cash outlays for clothing, durable goods, and farm equipment. Farms relied on the labor of all family members, supplemented by tenant families and some seasonal workers to produce vegetables and fruits, hay, corn, dairy products, and poultry. Farmsteads depended on kin and neighbors, participating in a "balanced reciprocity" that Adams describes in detail.

At mid-point the book shifts gears into a chronological mode to explain how rural people became dependent upon government assistance. During the Great Depression, the region's farm families experienced poverty so acute that, despite their earlier mistrust of the government, they welcomed New Deal programs. Adams argues that by World War II, rural people had come to accept the social safety net and economic regulation that the 
government provided. Two trends marked the postwar period of prosperity: mechanization, which reduced the number of farms and the number of laborers needed; and women's loss of control of dairying and poultry production, a change that would draw them into wage labor off the farm. Community life became ever more dependent on government agencies; these agencies undermined the power of elites and leveled the class structure. During the 1980s farm crisis, farming families suffered the tragic consequences of their misplaced faith in the government. Union County endured a demoralizing social crisis as farm prices collapsed, government support declined, and families lost farms.

Adams makes an important contribution to the rural literature on class and gender. While most studies recognize the presence of tenants but focus their attention on the land owners, Adams has the evidence to define the differences between renters and owners in Union County. She explains the absence of labor unrest as the result of a respectful distance through personalized relationships between people who were often relatives. The analysis of gender is thorough but asymmetrical. Adams persuasively argues for the economic centrality of women's work and against the applicability of urban-based historical models of domesticity. However, her relative lack of attention to men's lives leaves unanswered questions about the transformation in Union County.

How does the book succeed as history? Adams is more successful at describing the rural transformation than in identifying historical causality. In this telling, external forces such as the market or the government overpower the agency of farm people, who appear unable to shape structural change. The ethnographic detail does put a human face on that change, however. For example, she chronicles the story of a farmer whose strategy to market his corn on the hoof failed when hog prices plummeted during the Great Depression. Desperate not to lose the farm, he slaughtered his hogs and ground them into sausage for sale. One wishes Adams's informants might have said more about how they felt about their losses, not simply the steps they took to survive them. Adams also can be faulted for offering a fairly static portrayal of the 1890-1930 period, a time that Neth characterizes as full of massive changes in the system of family farming. While 
historians might profit from her creative use of social science theory, her work is not deeply rooted in rural historiography.

THESE THREE BOOKS rechannel the debate in rural history, moving it to new terrain both in time and in space. By arguing that households were complicit in the transformations from household to industrial production, the books synthesize a bipolar framework that had depicted farmers as either embracing or resisting market capitalism. Neither traditional nor modern, farm families adopted modern means to achieve traditional goals. In the process, shifts in gender roles and notions of class transformed family relationships. The study of the agrarian Midwest has now shifted its sights from advancing technologies to the intersections of culture, gender, and the state.

Future studies might profitably pay more attention to ethnicity and race to test the arguments made here about the primacy of rural culture. Rural politics should receive more attention as an arena for accommodation as well as resistance. Gender analysis should be expanded to test in rural settings recent arguments about the meaning of manhood. The importance of cropping patterns for work roles (obviously dairying lent itself to flexible gender roles) would make more regional studies welcome. Careful definitions of terms such as culture, capitalism, and competency would add greater precision to the discussion.

Ultimately, these books explain the broader meanings of economic transformations in agriculture for the lives of rural people. They demonstrate the dreadful power of progressive ideology and economic policy to transform rural society. The problems we see today in rural America-a declining and aging population, the disappearance of rural towns, environmental degradation - are consequences of a ruthless quest for economic efficiency. Books such as these have the potential not only to rewrite history, but also to guide us in charting the future. 
Copyright of Annals of Iowa is the property of State of Iowa, by \& through the State Historical Society of Iowa and its content may not be copied or emailed to multiple sites or posted to a listserv without the copyright holder's express written permission. However, users may print, download, or email articles for individual use. 